\title{
Biomass Deposition and Chemical Composition of Litterfall in Clonal Eucalyptus Plantations
}

\author{
Giovanno Radel de $\operatorname{Vargas}^{1}$ (D), Renato Marques ${ }^{1}$ (D), Jonas Eduardo Bianchin ${ }^{1}$ (D), \\ Wilson Wagner Ribeiro Teixeira ${ }^{1}$ (D), Hilbert Blum ${ }^{1}$ \\ ${ }^{1}$ Universidade Federal do Paraná - UFPR, Curitiba/PR, Brasil
}

\begin{abstract}
Productivity in clonal eucalyptus plantations depends on the genetic material and on the demand and cycling of nutrients, making studies that evaluate these requirements necessary. The aim of this study was to evaluate the effect of management (with and without thinning) on the deposition, chemical composition and nutrient contribution in litter at different clonal or stallion eucalyptus plantations. The experiment was conducted under a subdivided plot design for comparison of "clone" and "thinning" treatments. Plots were composed of eight different clonal and eucalyptus seed plantations, with subplots being areas where thinning was performed and areas without thinning. Litter deposition pattern associated to seasons was observed, with higher values in the spring and summer. The leaf fraction was more representative in relation to nutrients. Deposition values were close in most plantations. Nutritional contents were higher in leaves of areas with thinning in relation to the other areas.
\end{abstract}

Keywords: litter, clones, thinning. 


\section{INTRODUCTION AND OBJECTIVES}

The chemical elements essential to the life of plants are called nutrients and they circulate in ecosystems and biosphere in some specific ways between environment and organisms (Barlow et al., 2007). Trees remove nutrients from the soil and use them in their metabolism, which later return to the soil through litter deposition in a dynamic process called biogeochemical cycling (Corrêa et al., 2006). Litterfall deposition is considered the main flow in the biogeochemical cycling of nutrients that involves some steps such as: absorption, translocation and redistribution, immobilization and restitution of nutrients to the soil by plants that constitute the ecosystem (Bormann \& Likens, 1970).

In addition to being influenced by the plant succession stage and forest composition in an ecosystem, litterfall deposition is also influenced by other factors (Murovhi et al., 2012). Elements related to climate, in particular precipitation and temperature are among these factors, which act as regulators to variations that occur in litterfall deposition throughout the year, and also in the decomposition rate of this material (Correa et al., 2013). In this context, two common deposition patterns are observed in forest ecosystems in tropical regions. In the first one, there is an increase in deposition at periods of increased rainfall and humidity, for example in Atlantic restinga and forests; while in the second pattern, higher deposition is observed during dry seasons, for example in mesophilic forest regions and in some Amazon and Cerrado ecosystems (Brun et al., 2001; Calvi et al., 2009; Cattanio et al., 2004).

Some nutrients are retranslocated through biochemical cycling (internal to plants) from older leaves or tissues to younger ones, where intense growth is usually higher.

Thinning is a practice that interferes with nutrient cycling in forest plantations (Guo \& Sims, 1999). Due to the decrease in plant population, improvement in nutrient cycling and replenishment is expected, in addition to favoring the maintenance of soil fertility through litterfall decomposition. It is expected that stands in areas where thinning was performed generally present higher nutrient contents in the litterfall compared to areas without thinning (Silva et al., 2012).

Known effects of thinning are also related to tree growth, and several studies found in literature indicate that adequate thinning can lead plants to produce larger trunks (Poggiani \& Schumacher, 1997; Kolm \& Poggiani, 2003; Silva et al, 2012; Harrington \& Devine, 2011), thus increasing their primary productivity.

Through thinning evaluations, it is possible to define which clone best fits to this practice and whether its use can be recommended or not. Some studies can be found in literature on this topic, demonstrating the importance of defining the best genetic material to be used in each area (Pinto et al., 2011; Higashi et al., 2004; Lima et al., 2005).

The objectives of this study conducted in eucalyptus plantations with different genetic materials in areas submitted or not to forest thinning were: evaluating the seasonal effect on litterfall deposition; evaluating phytomass deposition by different litterfall fractions; characterizing the chemical composition (nutrients) of the different litterfall fractions and comparatively estimating the amount of nutrients that returns to the soil by the litterfall deposition process regarding different treatments.

\section{MATERIAL AND METHODS}

The study was conducted at the Estação Experimental de Ciências Florestais de Itatinga (EECFI), which belongs to the Escola Superior de Agricultura "Luiz de Queiroz"(ESALQ) - University of São Paulo (USP), located in Mid-southern region of the state of São Paulo at coordinates $23^{\circ} 10^{\prime} \mathrm{S}$ and $48^{\circ} 40^{\prime} \mathrm{W}$, municipality of Itatinga, a region belonging to the Paranapanema River basin.

EECFI has approximately 2119.6 ha of area. The relief of the area is predominantly slightly wavy with approximate altitude of $850 \mathrm{~m}$ a.s.l., with soils mainly classified as Red Latosols of sandy texture. The climate is defined as humid temperate with dry winter (Cwa) according to the Köppen classification. The average annual temperature is around $20^{\circ} \mathrm{C}$, with minimum temperatures during the year around $5^{\circ} \mathrm{C}$ and maximum temperatures around $30^{\circ} \mathrm{C}$ (INMET, 2017). The average annual precipitation is $1300 \mathrm{~mm}$ (Figure 1).

The original vegetation of the region is classified as Semi-deciduous Seasonal Forest, predominantly belonging to the Atlantic Forest biome (Metzger, 2009). The areas chosen to carry out the study were plots 
implanted in the year 2009, composed of eight clonal plantations and a stallion eucalyptus plantation with and without thinning (Figure 2). For each planting, 26 lines with 20 trees in each row, with $3.0 \times 2.0 \mathrm{~m}$ spacing between each other were considered before thinning and $26 \times 10$ plants and $3.0 \times 4.0 \mathrm{~m}$ spacing in the area where thinning was performed. Thinning was carried out during the months of October and November 2013 by removing half of the trees present in the thinned subplots.

Three litterfall collectors (Figure 3) were installed in each subplot, where leaves, reproductive organs (fruit, flowers and seeds) and vegetal residue (unidentified fine material) were collected, totaling 6 collectors per plot, and 54 collectors in the area. Collectors were systematically installed in clonal plantations between lines 5 and 6 of each subplot and between plants " 5 and 6", "11 and 12", and " 15 and 16" of each subplot to avoid contamination with materials from other clonal plantations.

To collect coarser litterfall fractions (from which branches and bark were collected), areas of $2.0 \times 1.0 \mathrm{~m}$ above the soil of each subplot were demarcated. Collection areas were positioned between lines " 5 and 6 " and between trees " 8 and 9" and " 13 and 14" of each subplot, isolated with identification tape (Figure 4). Each collection area had all litterfall material removed prior to the beginning of collections, leaving the soil exposed.

Collections were carried out monthly between April 2014 and March 2016, totaling 24 collections. Litterfall was separated into fractions, dried in an oven at $60-70^{\circ} \mathrm{C}$, then weighed to obtain the dry mass, being subsequently ground in a knife mill (Wiley type) for chemical determinations. Samples were submitted to nitrogen $(\mathrm{N})$, phosphorus $(\mathrm{P})$, potassium $(\mathrm{K})$, calcium

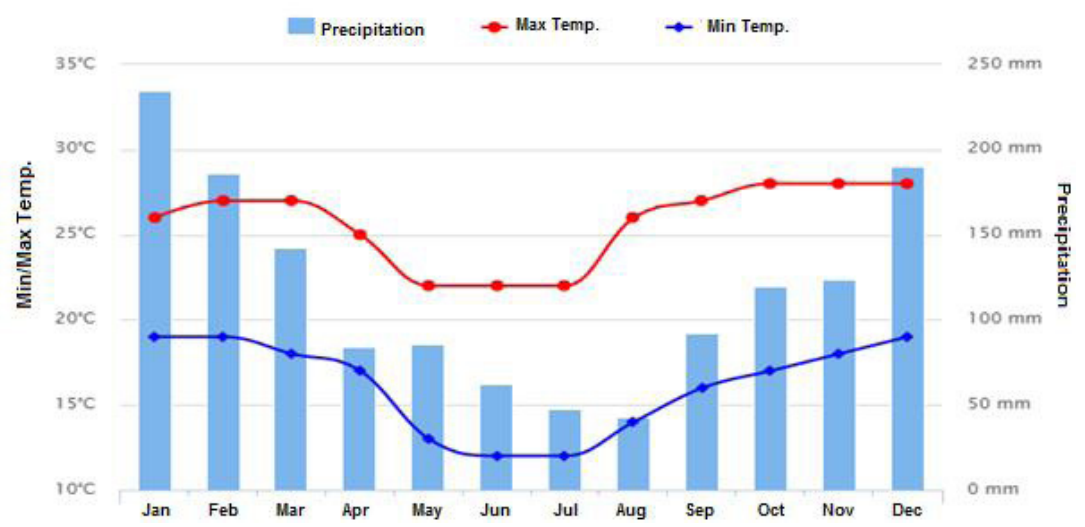

Figure 1. Maximum and minimum precipitation and temperature in Itatinga in the last 30 years.
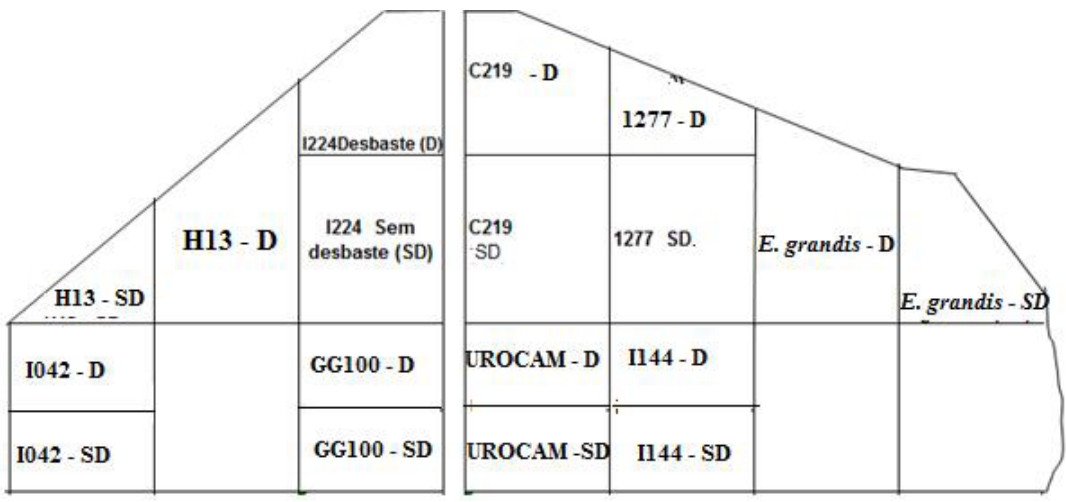

Figure 2. Scheme of the plantations' positioning in the field. 


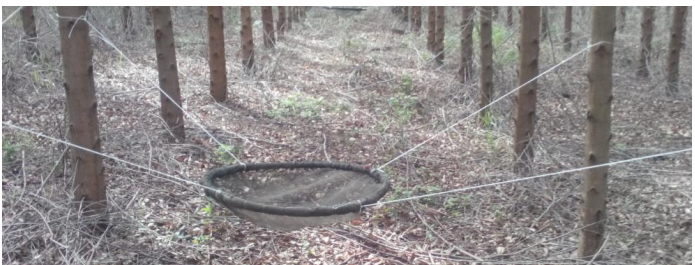

Figure 3. Litterfall collector.

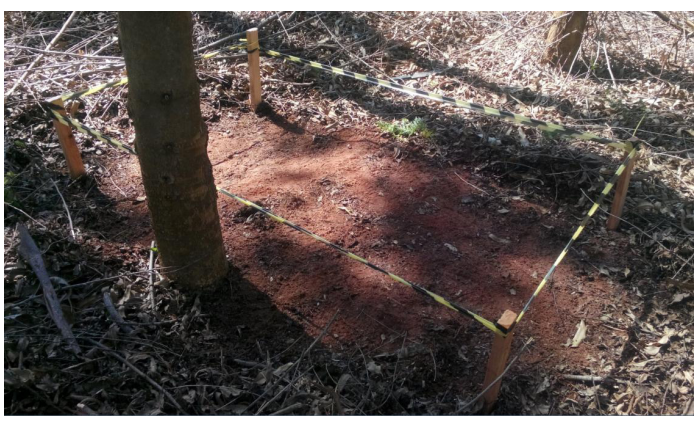

Figure 4. Collection area of branches and bark.

$(\mathrm{Ca})$ and magnesium $(\mathrm{Mg})$ determinations. $\mathrm{N}$ content was determined by combustion in CNHOS analyzer, ELEMENTAR, model Vario EL III. The other macronutrients were determined according to the dry digestion process by burning the plant material in muffle oven at $500^{\circ} \mathrm{C}$ and subsequent solubilization of chemical elements in ashes in $3 \mathrm{HClmol} \mathrm{L}^{-1}$ (Martins \& Reissmann, 2007). P was determined by colorimetry with vanadium-molybdate ammonium and read in UV/Vis 1240 Mini Shimadzu spectrophotometer. K was determined by flame photometry. $\mathrm{Ca}$ and $\mathrm{Mg}$ were determined by atomic absorption spectrophotometry.

The experiment was conducted under a subdivided plot design in order to compare "clones" and "thinning" treatments. Plots were composed by eight different clonal plantings and stallion planting, with subplots corresponding to areas with thinning $(\mathrm{T})$ and areas without thinning (WT).

Regarding the deposited litterfall phytomass, each collector was considered a replicate for comparison of treatments, as well as each collection date in the field; total replicates was obtained by multiplying the number of collectors (3) by the number of collections made throughout the study period (24).

Results were submitted to analysis of variance and Tukey test (5\% significance), for comparison of means (Pimentel-Gomes, 2009). Statistical analyses were performed using ASSISTAT software, version 7.5, developed at the Center of Technology and Natural Resources (Centro de Tecnologia e Recursos Naturais) of the Federal University of Campina Grande/PB.

\section{RESULTS AND DISCUSSION}

\subsection{Litterfall deposition}

Regardless of genetic material and presence or absence of thinning, litterfall showed deposition pattern characterized by higher deposition values in spring and summer, and lower values in autumn and winter (Figures 5 and 6). According to Viera et al. (2014), factors such as humidity and temperature strongly influence material deposition, so that litter deposition intensifies in months of higher temperature.

Laclau et al. (2010) observed that higher litterfall deposition in colder and drier months are typical characteristics of deciduous forests, while species such as eucalyptus have greater deposition period outside periods of lower water availability and lower temperatures.

Differences in litterfall deposition of eucalyptus plantations over time were also observed by Schumacher et al. (1994) in plantations at seven and ten years of age.

According to this author, this behavior is due to the greater translocation of organic compounds and nutrients from leaves in this period, and also to greater leaf renewal. Similar result was observed by Souza \& Davide (2001), Cunha et al. (2005) and Viera et al. (2014) in different regions of Brazil.

In a study evaluating progressive thinning in eucalyptus plantations in a climate region similar to that evaluated in this study, Kolm \& Poggiani (2003) found an increase of more than $60 \%$ in the amount of material deposited from November to March, coinciding with the hottest and rainy periods of the year. According to the authors, this behavior is due to the greater translocation of organic compounds and nutrients from leaves in this period, which also corresponds to greater leaf renewal. This result is similar to that observed by Viera et al. (2014) in an experiment conducted in southern Brazil, who also observed that factors such as humidity and temperature 


\section{Area without thinning}

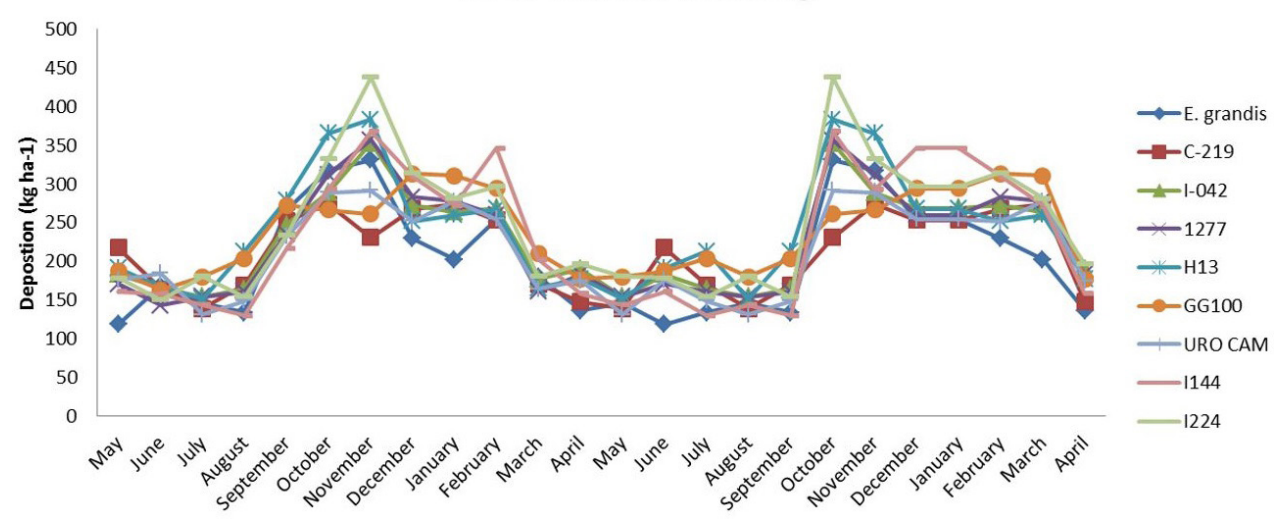

Figure 5. Total monthly litter deposition in area without thinning.

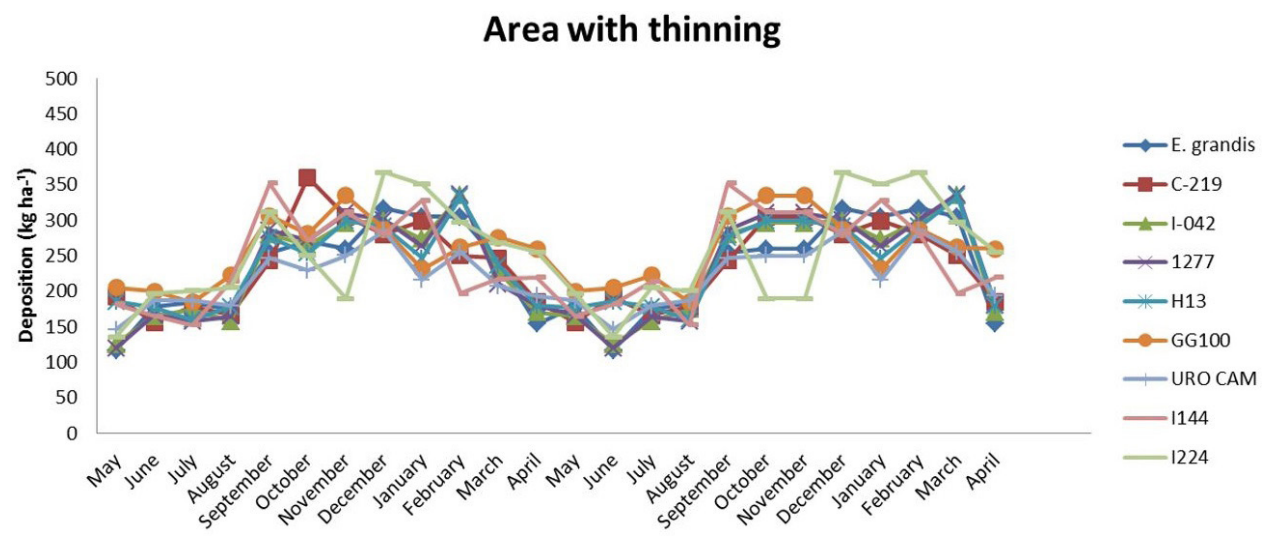

Figure 6. Total monthly litter deposition in area with thinning.

strongly influence material deposition, so that litterfall deposition intensifies in months of higher temperatures.

Differences in litterfall deposition in eucalyptus plantations over the months were also verified by Schumacher et al. (1994) in plantations at seven and ten years of age. Cunha et al. (2005) and Souza \& Davide (2001) reported that variations in litterfall deposition occur due to the cyclical characteristics of stands, in addition to biological and climatic factors; the authors also verified litterfall deposition peaks in the warmer and wetter months of the year in their studies.

No significant difference was observed between the different clonal plantations compared to each other and also comparing with stallion plantations, regardless of whether or not thinning was carried out (Table 1). The only exception occurred for clone I224, in which total litterfall deposition was significantly higher with thinning against without thinning.

No differences were observed comparing genetic materials to each other (mean values between areas with and without thinning), except for the residue fraction (Table 2). These differences are difficult to explain due to the diverse nature of this fraction.

Leaf deposition was much higher compared to the other litterfall fractions; the order of importance regarding the amount of litterfall deposited for most genetic materials evaluated was: Leaves $>$ Reproductive Organs $>$ Residues $>$ Branches $>$ Bark. Most phytomass that returns to the soil as litterfall in forest ecosystems (in both natural environments and in planted forests) is usually represented by leaves (Kolm \& Poggiani, 2003). Over time and with the increase of the system's 
Table 1. Average annual total litter deposition and different fractions in areas with and without thinning in each genetic material.

\begin{tabular}{|c|c|c|c|c|c|c|c|}
\hline \multirow[b]{2}{*}{ Planting } & \multirow[b]{2}{*}{ Thinning } & \multicolumn{6}{|c|}{ Phytomass (kg ha-1) } \\
\hline & & Leaves & $\begin{array}{l}\text { Reproductive } \\
\text { Organs }\end{array}$ & Bark & Branches & Residues & Total \\
\hline \multirow[t]{2}{*}{ E. grandis } & $\mathbf{T}$ & $1809 \mathrm{~A}$ & $409 \mathrm{~B}$ & 116 & 216 & $262 \mathrm{~B}$ & 2811 \\
\hline & WT & $1566 \mathrm{~B}$ & $661 \mathrm{~A}$ & 104 & 204 & $536 \mathrm{~A}$ & 3071 \\
\hline \multirow[t]{2}{*}{ C-219 } & $\mathrm{T}$ & 1939 & 465 & 108 & 233 & $155 \mathrm{~B}$ & 2899 \\
\hline & WT & 1800 & 541 & 123 & 218 & $525 \mathrm{~A}$ & 3206 \\
\hline \multirow[t]{2}{*}{ I-042 } & $\mathbf{T}$ & 1664 & 625 & 85 & 236 & $369 \mathrm{~B}$ & 2979 \\
\hline & WT & 1809 & 658 & 91 & 254 & $521 \mathrm{~A}$ & 3332 \\
\hline \multirow[t]{2}{*}{1277} & $\mathbf{T}$ & 1861 & $413 \mathrm{~B}$ & 82 & $157 \mathrm{~B}$ & $619 \mathrm{~B}$ & 3132 \\
\hline & WT & 1812 & $572 \mathrm{~A}$ & 110 & $210 \mathrm{~A}$ & $416 \mathrm{~A}$ & 3119 \\
\hline \multirow[t]{2}{*}{ H13 } & $\mathbf{T}$ & 1714 & 463 & 86 & $189 \mathrm{~B}$ & $672 \mathrm{~A}$ & 3124 \\
\hline & WT & 1804 & 581 & 93 & $295 \mathrm{~A}$ & $427 \mathrm{~B}$ & 3198 \\
\hline \multirow[t]{2}{*}{ GG100 } & $\mathrm{T}$ & 1937 & 498 & 96 & 194 & 626 & 3350 \\
\hline & WT & 1705 & 531 & 111 & 261 & 688 & 3294 \\
\hline \multirow[t]{2}{*}{ UROCAM } & $\mathbf{T}$ & $1678 \mathrm{~B}$ & 457 & 116 & 220 & $182 \mathrm{~B}$ & 2652 \\
\hline & WT & $2064 \mathrm{~A}$ & 533 & 110 & 215 & $348 \mathrm{~A}$ & 3269 \\
\hline \multirow[t]{2}{*}{ I144 } & $\mathrm{T}$ & $1809 \mathrm{~A}$ & 533 & 105 & 202 & $490 \mathrm{~A}$ & 3139 \\
\hline & WT & $1566 \mathrm{~B}$ & 646 & 100 & 225 & $304 \mathrm{~B}$ & 2840 \\
\hline \multirow[t]{2}{*}{$\mathrm{I} 224$} & $\mathbf{T}$ & 1939 & 674 & 101 & 246 & 584 & $3543 \mathrm{~A}$ \\
\hline & WT & 1800 & 549 & 108 & 214 & 429 & 3099B \\
\hline
\end{tabular}

Capital letters mean statistical difference between areas with and without thinning according to the Tukey test at $5 \%$ probability

(No letters mean that there were no differences between areas with and without thinning for each plantation).

age, leaf deposition tends to decrease proportionally to an increase in the fall of other components such as branches and reproductive organs, for example, at times of greater plant maturity; however, even with increasing planting age, leaves generally remain the largest source of litterfall in the vast majority of forest ecosystems (Laclau et al., 2010).

\subsection{Concentration of nutrients in the deposited litterfall}

The concentration of nutrients in the deposited litterfall for the different fractions throughout the year followed the following tendency: $\mathrm{N}>\mathrm{Ca}>\mathrm{Mg}>\mathrm{K}>\mathrm{P}$ levels (Table 2).

Data from Table 3 are annual mean values (mean between two years) of the 24 months of study period obtained from the average between areas with and without thinning.

In relation to $\mathrm{N}$, it was observed that some clones showed tendency of higher contents in relation to the others, with the highest values observed for H13, I277 and GG100 clones. No well-defined trends were found comparing the different fractions; in general, the decreasing sequence of the $\mathrm{N}$ content among the different fractions was: Leaves $>$ Branches $>$ Bark $>$ Reproductive Organs $>$ Plant residues.

According to Viera et al. (2014), $\mathrm{N}$ is observed in larger amounts than $\mathrm{Ca}$, especially when the latter is present in small amounts in the soil, which was also observed in this case. The highest Ca concentrations in relation to the other nutrients (with the general exception of $\mathrm{N}$ ), can be explained by its functions in the plant, as it is one of the main cell wall formers, in addition to being an element of small mobility in plants. Thus, after its arrival in leaves, it becomes immobile and practically does not redistribute again; also playing a structural function in trees, which explains the greater amount of $\mathrm{Ca}$ in the deposited material (Dias et al., 2002).

Regarding K, no clear differences among the different fractions were observed, which is possible because the element does not present a structural function and has high solubility. This can result in easy leaching of the different litterfall fractions. In relation to $\mathrm{P}$, a trend of higher $\mathrm{P}$ values in the leaf litterfall was observed 
Table 2. Annual total litter deposition and different fractions in the different genetic materials.

\begin{tabular}{|ccccccc|}
\hline & \multicolumn{5}{c}{ Phytomass $\left(\mathbf{k g ~ h a ~}^{-1}\right)$} \\
\cline { 2 - 8 } Clones & Leaves & $\begin{array}{c}\text { Reproductive } \\
\text { Organs }\end{array}$ & Bark & Branches & Residues & Total \\
\hline C219 & 1688 & 535 & 110 & 210 & $399 \mathrm{~b}$ & 2941 \\
\hline I-042 & 1870 & 503 & 115 & 225 & $340 \mathrm{~b}$ & 3053 \\
\hline $\mathbf{1 2 7 7}$ & 1737 & 642 & 88 & 245 & $445 \mathrm{~b}$ & 3156 \\
\hline H13 & 1837 & 492 & 96 & 183 & $518 \mathrm{a}$ & 3125 \\
\hline GG100 & 1759 & 522 & 89 & 242 & $549 \mathrm{a}$ & 3161 \\
\hline UROCAM & 1821 & 514 & 103 & 227 & $657 \mathrm{a}$ & 3322 \\
\hline I144 & 1871 & 495 & 113 & 217 & $265 \mathrm{c}$ & 2961 \\
\hline I224 & 1688 & 590 & 102 & 213 & $397 \mathrm{~b}$ & 2990 \\
\hline
\end{tabular}

Means followed by the same letter in column do not differ statistically by the Tukey test at $5 \%$ probability. Lowercase letters compare clones to each other when there is statistical difference.

Table 3. Annual concentration of nutrients in litter deposited per fraction.

\begin{tabular}{|c|c|c|c|c|c|c|c|c|c|}
\hline Fraction & E. grandis & C-219 & I-042 & 1277 & H13 & GG100 & UROCAM & I144 & I224 \\
\hline \multicolumn{10}{|c|}{$\mathbf{N}\left(\mathrm{g} \mathrm{kg}^{-1}\right)$} \\
\hline DL & 15.8 & 13.7 & 18.0 & 21.6 & 21.8 & 20.8 & 15.8 & 17.7 & 17.3 \\
\hline BN & 14.2 & 16.8 & 13.4 & 12.2 & 14.3 & 12.3 & 16.6 & 10.9 & 19.6 \\
\hline BK & 12.5 & 10.5 & 10.7 & 13.3 & 12.7 & 18.7 & 15.6 & 10.8 & 17.5 \\
\hline RO & 10.8 & 13.5 & 11.5 & 14.8 & 12.3 & 16.3 & 12.7 & 10.3 & 13.2 \\
\hline RE & 10.6 & 11.2 & 13.5 & 8.5 & 15.3 & 15.3 & 9.5 & 10.6 & 9.6 \\
\hline \multicolumn{10}{|c|}{$P\left(\mathrm{~g} \mathrm{~kg}^{-1}\right)$} \\
\hline DL & 1.0 & 0.9 & 0.9 & 0.7 & 0.9 & 1.1 & 1.1 & 0.9 & 0.8 \\
\hline BN & 0.5 & 0.5 & 0.4 & 0.6 & 0.5 & 0.7 & 0.9 & 0.9 & 0.5 \\
\hline BK & 0.7 & 0.5 & 0.9 & 0.6 & 0.7 & 0.7 & 0.8 & 0.5 & 0.4 \\
\hline RO & 0.6 & 0.3 & 0.5 & 0.5 & 1.0 & 1.0 & 0.6 & 0.5 & 0.3 \\
\hline RE & 0.6 & 0.3 & 0.6 & 0.6 & 0.7 & 0.7 & 0.7 & 0.4 & 0.4 \\
\hline \multicolumn{10}{|c|}{$\mathrm{K}\left(\mathrm{g} \mathrm{kg}^{-1}\right)$} \\
\hline DL & 1.2 & 1.5 & 1.6 & 1.5 & 1.6 & 1.7 & 1.6 & 1.5 & 1.5 \\
\hline BN & 1.0 & 0.9 & 1.3 & 1.3 & 1.4 & 1.4 & 1.8 & 1.4 & 1.3 \\
\hline BK & 1.9 & 1.5 & 2.1 & 1.1 & 1.3 & 1.3 & 1.2 & 1.7 & 1.6 \\
\hline RO & 1.3 & 1.1 & 1.2 & 1.1 & 1.3 & 1.3 & 1.2 & 1.2 & 1.3 \\
\hline RE & 2.2 & 1.9 & 1.1 & 1.8 & 1.6 & 1.6 & 1.8 & 1.2 & 1.8 \\
\hline \multicolumn{10}{|c|}{$\mathrm{Ca}\left(\mathrm{g} \mathrm{kg}^{-1}\right)$} \\
\hline DL & 8.9 & 7.6 & 7.7 & 7.4 & 9.1 & 8.5 & 10.9 & 8.5 & 9.9 \\
\hline BN & 6.3 & 5.3 & 8.4 & 7.3 & 6.2 & 6.2 & 7.0 & 6.3 & 5.3 \\
\hline BK & 10.5 & 11.3 & 9.8 & 10.7 & 9.2 & 9.2 & 9.4 & 10.5 & 8.4 \\
\hline RO & 7.5 & 10.6 & 7.8 & 8.4 & 5.3 & 5.3 & 6.2 & 4.9 & 10.2 \\
\hline $\mathrm{RE}$ & 5.3 & 3.2 & 10.6 & 10.3 & 5.1 & 5.1 & 9.4 & 7.2 & 7.6 \\
\hline \multicolumn{10}{|c|}{$\operatorname{Mg}\left(\mathrm{g} \mathrm{kg}^{-1}\right)$} \\
\hline DL & 3.8 & 4.2 & 4.0 & 5.3 & 4.3 & 4.8 & 4.7 & 4.3 & 4.9 \\
\hline BN & 1.9 & 3.2 & 4.2 & 3.7 & 3.5 & 2.5 & 2.5 & 3.5 & 2.2 \\
\hline BK & 2.6 & 3.6 & 4.2 & 2.9 & 2.9 & 1.9 & 3.0 & 3.1 & 3.2 \\
\hline RO & 2.9 & 2.0 & 4.1 & 3.6 & 2.6 & 2.6 & 3.4 & 3.1 & 3.3 \\
\hline RE & 2.9 & 2.3 & 4.0 & 3.9 & 4.0 & 3.0 & 3.0 & 3.2 & 3.8 \\
\hline
\end{tabular}

$\mathrm{DL}=$ diverse leaves; $\mathrm{BN}=$ branches; $\mathrm{BK}=$ bark; $\mathrm{RO}=$ reproductive organs; $\mathrm{RE}=$ residues. 
compared to the other fractions. For Mg, the observed sequence was Leaves $>$ Bark $>$ Plant Residue $>$ Reproductive Organs $>$ Branches, which was also expected in the case of leaves as it is also one of the structural components of the chlorophyll molecule.

Regarding the nutrient contents in leaf litterfall in comparing subplots with thinning $(\mathrm{T})$ and without thinning (WT), a single case of content difference was identified for Ca in the stallion plantation (E. grandis). No effect of thinning was observed for the other elements regarding leaf litterfall among the different clones (Table 4).

The removal of some trees from the stands through thinning should promote improvements in the growth conditions of the remaining treessuch as better use of light, water and nutrients (for example) due to less competition between plants, leading to a forest increment in the trees that were not eliminated,and to greater efficiency in absorption and utilization of the nutrients in the period after thinning (Gorgens et al., 2007). Thus, it was expected that the nutrient concentrations in the area with and without thinning would present a greater differences between them, which was not observed.

\subsection{Amount of nutrients in the deposited litterfall}

The amount of nutrients in the litterfall deposited throughout the year in both areas with and without thinning generally followed the trend: $\mathrm{N}>\mathrm{Ca}>\mathrm{Mg}>\mathrm{K}>\mathrm{P}$ (Table 5).

By evaluating the amounts of nutrients of different genetic materials, it is possible to observe some well-defined trends for certain nutrients. No differences

Table 4. Nutrient concentration in leaves of the deposited litter.

\begin{tabular}{|c|c|c|c|c|c|c|c|c|c|c|}
\hline \multirow{3}{*}{ Planting } & \multicolumn{2}{|c|}{$\mathbf{N}$} & \multicolumn{2}{|c|}{$\mathbf{P}$} & \multicolumn{2}{|c|}{$\mathbf{K}$} & \multicolumn{2}{|c|}{$\mathrm{Ca}$} & \multicolumn{2}{|c|}{ Mg } \\
\hline & \multicolumn{10}{|c|}{--------------------------------g kg } \\
\hline & $\mathbf{T}$ & WT & $\mathbf{T}$ & WT & $\mathbf{T}$ & WT & $\mathbf{T}$ & WT & $\mathbf{T}$ & WT \\
\hline E.grandis & 15.3 & 16.4 & 1.2 & 0.9 & 1.5 & 1.0 & $12.0 \mathrm{~A}$ & $5.8 \mathrm{~B}$ & 4.0 & 3.6 \\
\hline C-219 & 13.3 & 14.2 & 0.9 & 1.0 & 1.4 & 1.7 & 9.4 & 5.8 & 4.4 & 4.0 \\
\hline I-042 & 18.2 & 17.8 & 1.0 & 0.8 & 1.4 & 1.8 & 9.8 & 5.6 & 3.8 & 4.2 \\
\hline 1277 & 20.0 & 23.2 & 0.6 & 0.9 & 1.6 & 1.4 & 8.6 & 6.2 & 5.4 & 5.3 \\
\hline H13 & 21.6 & 22.1 & 1.0 & 0.9 & 1.8 & 1.5 & 9.0 & 9.2 & 4.8 & 3.9 \\
\hline GG100 & 22.0 & 19.7 & 1.2 & 1.0 & 1.8 & 1.6 & 9.6 & 7.4 & 5.2 & 4.4 \\
\hline URCAM & 16.3 & 15.4 & 1.0 & 1.2 & 1.7 & 1.6 & 11.0 & 10.8 & 5.2 & 4.3 \\
\hline I144 & 19.3 & 16.1 & 0.8 & 1.0 & 1.5 & 1.6 & 9.4 & 7.6 & 4.6 & 4.1 \\
\hline I224 & 17.7 & 16.9 & 0.8 & 0.9 & 1.4 & 1.6 & 9.8 & 10.0 & 4.7 & 5.1 \\
\hline
\end{tabular}

Capital letters mean statistical difference between areas with and without thinning for each plantation according to the Tukey test at $5 \%$ probability (No letters mean that there were no differences between areas with and without thinning for each plantation).

Table 5. Annual amount of nutrients in litter deposited.

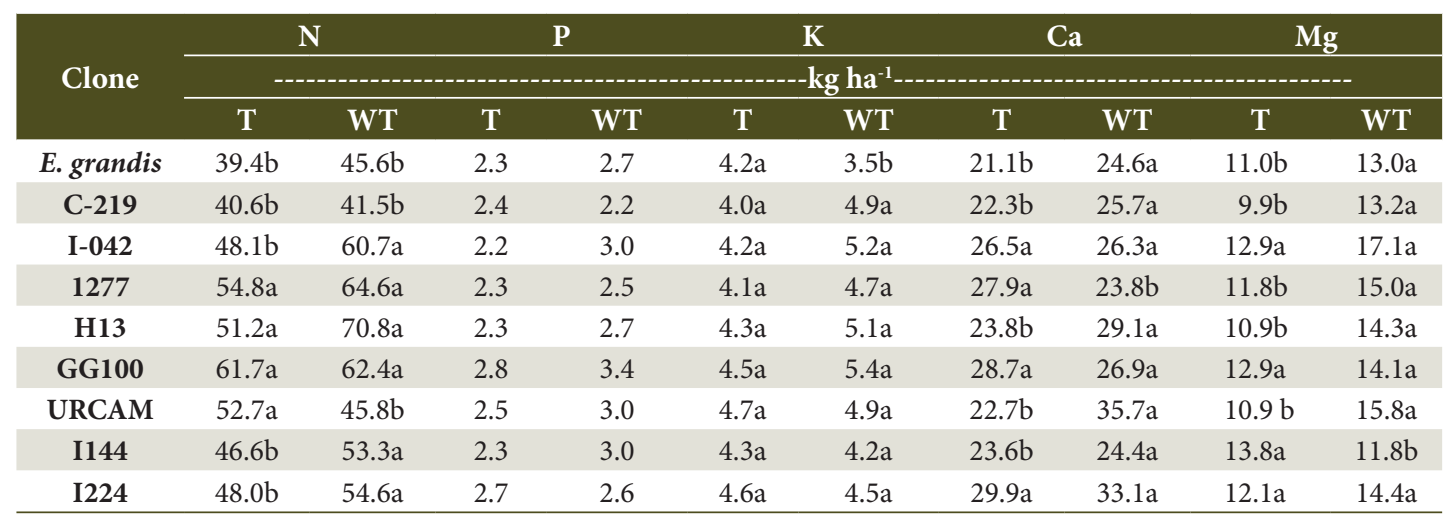

Means followed by the same letter in column do not differ statistically by the Tukey test at $5 \%$ probability. Lowercase letters compare clones to each other when there is statistical difference. 
were found for the genetic materials between areas with and without thinning.

For N, no differences were observed when comparing areas with and without thinning for any of the genetic materials, and to date there was no influence of thinning on the amounts of this nutrient in the deposited material. There was no statistical differencein relation to $\mathrm{P}$, as the genetic material presented values close to one another and also when comparing areas with and without thinning in each case.

When comparing the genetic material in relation to $\mathrm{K}$, the area without thinning of the stallion plantation presented a lower value than the others, while the other evaluated areas presented values close to one another.

No differences were observed for Ca when comparing areas with and without thinning for any of the genetic materials. When comparing the genetic materials to one another, the materials UROCAM and C219 in the area with thinning, and clone 1277 in the area without thinningpresented smaller amounts than the other genetic materials. No differences between areas with and without thinning were observed for $\mathrm{Mg}$.

The amounts of $\mathrm{N}$ for most genetic materials are similar to those of Eucalyptus plantations found in literature (Turner \& Lambert, 1983). The amounts of $\mathrm{P}$ are similar to those found in literature, including in studies on $\mathrm{N}$ and also according to Negi et al. (1988) and Gonçalves et al. (1997). In most evaluated genetic materials, $\mathrm{Ca}, \mathrm{Mg}$ and $\mathrm{K}$ values are below those reported in studies on $\mathrm{N}$ and $\mathrm{P}$.

It could be observed that all plantations in the studies above were at advanced ages in relation to the evaluated areas, demonstrating that the return of nutrients via litterfall deposition at this stage of plant development was low for the majority of nutrients evaluated in relation to values usually observed in literature for Eucalyptus.

\section{CONCLUSIONS}

There is a pattern of litterfall deposition associated with the seasons of the year, presenting higher values in spring and summer. Different litterfall fractions contribute in a different way to the amount of phytomass that returns to the soil, in which the leaf fraction was the most representative. In general, fraction sequences with higher nutrient contents were: leaves $>$ branches $>$ bark $>$ reproductive organs $>$ residues.

Total litterfall deposition was similar for most clones in both subplots. Nutritional contents were higher in leaf litterfall in areas with thinning for most of the genetic material despite the few statistical differences, and the sequence of nutritional contents in litterfall fractions was $\mathrm{N}>\mathrm{Ca}>\mathrm{Mg}>\mathrm{K}>\mathrm{P}$.

\section{SUBMISSION STATUS}

Received: 7 apr., 2017

Accepted: 14 feb., 2018

\section{CORRESPONDENCE TO}

\section{Giovanno Radel de Vargas}

Departamento de Solos e Engenharia Agrícola, Universidade Federal do Paraná - UFPR, Rua dos Funcionários, 1540, CEP 80035-060, Curitiba, PR, Brasil

e-mail:dinidio@gmail.com

\section{REFERENCES}

Barlow J, Gardner TA, Ferreira LV, Peres CA. Litter fall and decomposition in primary, secondary and plantation forests in the Brazilian Amazon. Forest Ecology and Management 2007; 247(1-3): 91-97. http://dx.doi. org/10.1016/j.foreco.2007.04.017.

Bormann HF, Likens GE. The nutrient cycles of an ecosystem. Scientific Amazon 1970; 233: 92-101.

Brun EJ, Schumacher MV, Spathelf P. Relação entre a produção de serapilheira e variáveis meteorológicas em três fases sucessionais de uma Floresta Estacional Decidual no Rio Grande do Sul. Revista Brasileira de Agrometeorologia 2001; 9: 277-285.

Calvi GP, Pereira MG, Espíndula A Jr. Produção de serapilheira e aporte de nutrientes em áreas de floresta atlântica em Santa Maria de Jetibá, ES. Ciência Florestal 2009; 19(2): 13-138. http://dx.doi.org/10.5902/19805098404.

Cattanio JH, Anderson AB, Rombold JS, Nepstad DC. Phenology, litterfall, growth, and root biomass in a tidal floodplain forest in the Amazon estuary. Revista Brasileira de Botanica. Brazilian Journal of Botany 2004; 27(4): 703712. http://dx.doi.org/10.1590/S0100-84042004000400010.

Corrêa FLO, Ramos JD, Gama-Rodrigues ACG, Müller MW. Produção de serapilheira em sistema agroflorestal multiestratificado no estado de Rondônia, Brasil. Ciência e Agrotecnologia 2006; 30(6): 1099-1105. http://dx.doi. org/10.1590/S1413-70542006000600008. 
Correa RS, Schumacher MV, Momolli DR. Deposição de serapilheira e macronutrientes em povoamento de EucalyptusdunniiMaiden sobre pastagem natural degradada no Bioma Pampa. Scientia Forestalis 2013; 97: 65-74.

Cunha GM, Gama-Rodrigues AC, Costa GS. Ciclagem de nutrientes em Eucalyptusgrandis W. Hill exMaiden no norte fluminense. Árvore 2005; 29:353-363.

Dias HCT, Figueira MD, Silveira V, Fontes MAL, Oliveira AT, Scolforo JRS. Variação temporal de nutrientes na serapilheira de um fragmento de Floresta Estacional Semidecidual em Lavras, Minas Gerais - Brasil. Cerne 2002; 8: 1-16.

Gonçalves JLM, Barros NF, Nambiar EKS, Novais RF. Soil and stand management for short-rotation plantations. In: Nambiar EDS, Brown AG. Management of soil nutrients and water in tropical plantations forest. Canberra: ACIAR; 1997.

Gorgens EB, Leite HG, Nogueira GS, Dias AN. Tendência de crescimento de povoamento de eucalipto após aplicação de desbaste. Revista Árvore 2007; 31(5): 879-885. http:// dx.doi.org/10.1590/S0100-67622007000500012.

Guo LB, Sims REH. Litter decomposition and nutrient release via litter decomposition in the New Zealand eucalypt short rotation forests. Agriculture, Ecosystems \& Environment 1999; 75(1-2): 133-140. http://dx.doi. org/10.1016/S0167-8809(99)00069-9.

Harrington CA, Devine WD. Stand development following precommercial thinning and fertilization treatments in a Western redcedar (Thujaplicata) dominated forest. Canadian Journal of Forest Research 2011; 41(1): 151-164. http://dx.doi.org/10.1139/X10-193.

Higashi EN, Silveira LVA, Gonçalves AN. Nutritional monitoring and fertilization in clonal macro, mini, and microgardens. In: Gonçalves JLM, editores. Forest nutrition and fertilization. Piracicaba: IPEF; 2004.

Instituto Nacional de Meteorologia - INMET. [online]. 2017 [cited 2017 Jan 11]. Available from: http://www. inmet.gov.br/

Kolm L, Poggiani F. Ciclagem de nutrientes em povoamentos de Eucalyptusgrandis submetidos à prática de desbastes progressivos. Scientia Forestalis 2003; 63: 79-93.

Laclau J-P, Ranger J, Gonçalves JLM, Maquère V, Krusche AV, M'Bou AT et al. Biogeochemical cycles of nutrients in tropical Eucalyptus plantations main features shown by intensive monitoring in Congo and Brazil. Forest Ecology and Management 2010; 259(9): 1771-1785. http://dx.doi. org/10.1016/j.foreco.2009.06.010.

Lima AMN, Neves JCL, Silva IR, Leite FP. Cinética de absorção e eficiência nutricional de K, Ca e Mg em plantas jovens de quatro clones de eucalipto. Revista Brasileira de Ciência do Solo 2005; 29(6): 903-909. http://dx.doi. org/10.1590/S0100-06832005000600008.
Martins APL, Reissmann CB. Material vegetal e as rotinas laboratoriais nos procedimentos químico-analíticos. Scientia Agraria 2007; 8(1):1-17, 2007. http://dx.doi. org/10.5380/rsa.v8i1.8336.

Metzger JP. Conservation issues in the Brazilian Atlantic forest. Biological Conservation 2009; 142(6): 1138-1140. http://dx.doi.org/10.1016/j.biocon.2008.10.012.

Murovhi NR, Materechera AS, Mulugeta SD. Seasonal changes in litter fall and its quality from three sub-tropical fruit tree species at Nelspruit, South Africa. Agroforestry Systems 2012; 86(1): 61-71. http://dx.doi.org/10.1007/ s10457-012-9508-6.

Negi JDS, Sharma SC, Bisht APS. Forest floor and soil nutrient inventories in an old growth Eucalyptus plantations. Indian Forester 1988; 114: 453-461.

Pimentel-Gomes F. Curso de estatística experimental. 15. ed. Piracicaba: FEALQ - Fundação de Estudos Agrários Luiz de Queiroz; 2009.

Pinto SIC, Furtini-Neto AE, Neves JCL, Faquin V, Moretti BS. Eficiência nutricional de clones de eucalipto na fase de mudas cultivados em solução nutritiva. Revista Brasileira de Ciência do Solo 2011; 35(2): 523-533. http://dx.doi. org/10.1590/S0100-06832011000200021.

Poggiani F, Schumacher MV. Atmospheric inputs compared with nutrient removed by harvesting from Eucalyptus plantation. Implications for sustainability; 1997; Colombo. In: IUFRO Conference on Silviculture and improvement for Eucalypt. Colombo: CNPF; EMBRAPA; 1997.

Schumacher MV, Poggiani F, Simões JW. Transferência de nutrientes das copas para o solo através da deposição de folhedo em povoamentos de Eucalyptuscamaldulensis, Eucalyptusgrandis, Eucalyptustorelliana plantados em Anhembi-SP. IPEF 1994; 47: 56-61.

Silva JV, Nogueira GS, Santana RC, Leite HG, Oliveira MLR, Almado RP. Produção e acúmulo de nutrientes em povoamento de eucalipto em consequência da intensidade do desbaste e da fertilização. Pesquisa Agropecuária Brasileira 2012; 47(11): 1555-1562. http://dx.doi.org/10.1590/S0100204X2012001100001.

Souza JA, Davide AC. Deposição de serapilheira e nutrientes em uma mata não minerada e em plantações de bracatinga (Mimosa scabrella) e de eucalipto (Eucalyptussaligna) em áreas de mineração de bauxita. Cerne 2001; 7: 101-113.

Turner J, Lambert MJ. Nutrient cycling within a 27-yearsold Eucalyptus grandis plantation in New South Wales. Forest Ecology and Management 1983; 6(2): 155-168. http:// dx.doi.org/10.1016/0378-1127(83)90019-1.

Viera M, Schumacher MV, Araújo EF, Corrêa RS, Caldeira MVW. Deposicao de Serapilheira e Nutrientes em Plantio de Eucalyptusurophylla $\times$ E. globulus. Floresta e Ambiente 2014; 21(3): 327-338. http://dx.doi.org/10.1590/21798087.053913 . 